\title{
Third and Fourth Degree Statistics-Based Genetics of Quantitative Traits in Dolichos Bean (Lablab purpureus L.)
}

\author{
B.M. Showkath Babu ${ }^{1 *}$, B.N. Jagadeesh ${ }^{2}$, S. Ramesh ${ }^{1}$, C.M. Keerthi ${ }^{1}$ and H.H. Sowmya ${ }^{1}$ \\ ${ }^{1}$ Department of Genetics and Plant Breeding, College of Agriculture, University of Agricultural \\ Sciences (UAS), Gandhi Krishi Vignana Kendra (GKVK), Bengaluru 560-065, Karnataka, India \\ ${ }^{2}$ Dryland Agriculture Project (DLAP), University of Agricultural Sciences (UAS), Gandhi Krishi \\ Vignana Kendra (GKVK), Bengaluru 560-065, Karnataka, India \\ *Corresponding author
}

A B S T R A C T

\begin{tabular}{|c|c|}
\hline & \multirow{6}{*}{$\begin{array}{l}\text { Very often, genetics of quantitative traits is unraveled using first (mean) and/or second } \\
\text { degree statistics (variance) and their derivatives. Genetic analysis based on skewness, the } \\
\text { third degree statistics and kurtosis, the fourth degree statistics is more powerful and useful } \\
\text { than first and second degree statistics, especially for detecting and characterizing the } \\
\text { nature of epistasis. An investigation was carried out to unravel and interpret genetics of } \\
\text { fresh pod yield and its component traits using skewness and kurtosis estimated in } F_{2} \text { and } F_{3} \\
\text { populations derived from two crosses of dolichos bean, one of the important food grain } \\
\text { legume extensively grown in India. The positively skewed platykurtic distribution of } F_{2} \\
\text { and } F_{3} \text { populations derived from the two crosses indicated the role of large number of } \\
\text { increasing effects genes with majority of them displaying complementary epistasis in the } \\
\text { expression of most of the traits. The expected gain is slow with mild selection while it is } \\
\text { rapid with intense selection for the improvement of the traits investigated. The study } \\
\text { provided comprehensive and mutually complementary information on the mode of action } \\
\text { of gene controlling fresh pod yield and its component traits based on third and fourth } \\
\text { degree statistics. }\end{array}$} \\
\hline Keywords & \\
\hline $\begin{array}{l}\text { Dolichos bean, } \\
\text { Genetics, } \\
\text { Quantitative traits, } \\
\text { Third and fourth } \\
\text { degree statistics. }\end{array}$ & \\
\hline Article Info & \\
\hline $\begin{array}{l}\text { Accepted: } \\
\text { 21 September } 2017 \\
\text { Available Online: } \\
10 \text { October } 2017\end{array}$ & \\
\hline & \\
\hline
\end{tabular}

\section{Introduction}

Dolichos bean (Lablab purpureus L.), commonly known as field bean, hyacinth bean, Indian bean, Egyptian bean, Bonavist bean, Sem, etc. is a grain legume species and belongs to family Fabaceae. It is predominantly a self-pollinated crop. Based on the relative length of the pods and the angle of attachment of seeds to the suture of pods, two botanical types of dolichos bean are recognized. They are Lablab purpureus var. typicus and L. purpureus var. lignosus. The pods are flat, longer and tapering and the seeds are arranged parallel to suture of pods in var. typicus, while the pods are relatively shorter and more abruptly truncated and the seeds are arranged perpendicular to the suture of pods in var. lignosus. While, L. purpureus var. typicus is predominantly grown for whole pods for use as a vegetable, L. purpureus var. lignosus is primarily grown for fresh immature grains for use as a vegetable. The grains serve as one of the important sources of protein to the people depending on vegetarian diet. In India, dolichos bean, var. 
lignosus is being cultivated both as a pure crop and intercrop in irrigated and rainfed ecosystems, respectively in Southern Karnataka and adjoining districts of Andhra Pradesh and Tamil Nadu. In pure crop stands, the productivity of dry seed yield is $1.2 \mathrm{t} \mathrm{ha}^{-1}$ (1) while it is 0.4 to $0.5 \mathrm{t} \mathrm{ha}^{-1}$ in inter-cropping system.

The crop has evolved as a photoperiod sensitive short-day species with indeterminate growth habit. It requires short-days for transition from vegetative to reproductive phase. Photoperiod sensitivity has restricted its cultivation only in short season. Farmers normally cultivate traditional photoperiod sensitive in-determinate type cultivars with location-specific crop management practices. Though a few high yielding photoperiod insensitive determinate type cultivars have been developed, narrow range of their adaptation limits their cultivation in all the target regions planted to dolichos bean. Therefore, the productivity of dolichos bean in farmer's field $\left(1.2 \mathrm{t} \mathrm{ha}^{-1}\right)$ is rather low compared to its potential productivity $\left(2.0 \mathrm{t} \mathrm{ha}^{-1}\right)$ under wellmanaged production practices. Development and deployment of high-yielding cultivars with a range of maturity that match the production environment in target regions offer wider choices to the farmers and contribute to sustainable production due to cultivar diversity (2). Effectiveness of breeding dolichos bean hinges on comprehensive information on genetics of target traits. Genetics of quantitative traits could be unraveled at first, second, third and fourth degree statistics levels. The skewness, the third degree statistics and kurtosis, the fourth degree statistics are more powerful and useful than first (mean) and second degree (variance) statistics and their derivatives, especially for detecting and characterizing the nature of epistasis. Under these premises, the present investigation was carried out to unravel the genetics of fresh pod yield and its component traits at third and fourth degree statistics levels in dolichos bean.

\section{Materials and Methods}

\section{Basic genetic material}

The basic material for the study consists of three parent's viz., HA 10-8, FPB 21 (advanced breeding lines) and RIL 180 (a recombinant inbred line). The genotypes are being maintained at All India Co-ordinated Research Project (AICRP) on pigeonpea, Zonal Agricultural Research Station (ZARS), University of Agricultural Sciences (UAS), Bengaluru, India.

\section{Development of experimental material}

The two advanced breeding lines (HA 10-8 and FPB 21) designated as females were crossed with RIL 180 during 2011 rainy season. The two $F_{1}$ 's, HA 10-8 $\times$ RIL 180 $\left(\mathrm{C}_{1}\right)$ and FPB $21 \times \mathrm{RIL} 180\left(\mathrm{C}_{2}\right)$ were grown at the experimental plots of Department of Genetics and Plant Breeding (GPB), UAS, Bengaluru during 2012 rainy season and were selfed to develop $F_{2}$ populations. The $F_{2}$ population derived from crosses, $\mathrm{C}_{1}$ and $\mathrm{C}_{2}$ were grown with inter-row spacing of $0.60 \mathrm{~m}$ and a spacing of $0.30 \mathrm{~m}$ between plants within a row at the experimental plots of Department of GPB, UAS, Bengaluru during 2013 rainy season and were selfed to develop $F_{3}$ populations. The selfed seeds from the three parents and their $F_{1}, F_{2}$ and $F_{3}$ generations constituted the experimental material.

\section{Evaluation of experimental material}

The parents HA 10-8 $\left(\mathrm{P}_{1}\right)$, FPB $21\left(\mathrm{P}_{2}\right)$ and RIL $180\left(\mathrm{P}_{3}\right)$ and the two crosses HA 10-8 $\times$ RIL $180\left(\mathrm{C}_{1}\right)$ and FPB $21 \times \mathrm{RIL} 180\left(\mathrm{C}_{2}\right)$ were evaluated in RCBD with two replications. The $\mathrm{F}_{2}$ and $\mathrm{F}_{3}$ generations of the two crosses were evaluated in two separate 
contiguous blocks at Dry Land Agriculture Project (DLAP), UAS, Bengaluru. Geographically, DLAP, Bengaluru is located at $12^{\circ} 58^{\prime}$ latitude North , $77^{\circ} 35^{\prime}$ longitude East and an altitude of 930 meters above mean sea level. The annual rainfall ranges from $679.1 \mathrm{~mm}$ to $888.9 \mathrm{~mm}$. The $\mathrm{P}_{1}, \mathrm{P}_{2}$ and $\mathrm{F}_{1}$ 's of each cross were grown in a single row of $3.0 \mathrm{~m}$ length with intra-plant spacing of $0.30 \mathrm{~m}$ in each replication during 2014 postrainy season. About $212 \mathrm{~F}_{2}$ plants of HA 10-8 $\times$ RIL 180 and 229 plants of FPB $21 \times$ RIL 180 crosses were maintained in 21 and 23 rows respectively, containing 10 plants each with an inter-row spacing of $0.45 \mathrm{~m}$ and interplant spacing of $0.30 \mathrm{~m}$.

Seeds collected from the 17 and 31 random $F_{2}$ plants of crosses; HA 10-8 $\times$ RIL 180 and FPB $21 \times$ RIL 180, respectively were grown in plant to row progenies, each consisting of 12 plants. Each $\mathrm{F}_{3}$ progeny families of the two crosses were evaluated in augmented design (Federer, 1961) in two blocks each. Each block consisted of 8 and $9 \mathrm{~F}_{3}$ progeny families derived from HA 10-8 $\times$ RIL 180 cross, while 15 and $16 \mathrm{~F}_{3}$ progeny families derived from FPB $21 \times$ RIL 180 cross were grown in a single row of $3.0 \mathrm{~m}$, with an interrow spacing of $0.45 \mathrm{~m}$ length and inter-plant spacing of $0.20 \mathrm{~m}$. The data on nine quantitative traits such as plant height $(\mathrm{cm})$, primary branches plant ${ }^{-1}$, days to flowering, racemes plant ${ }^{-1}$, raceme length $(\mathrm{cm})$, fresh pods raceme ${ }^{-1}$, fresh pods plant $^{-1}$,fresh pod yield plant $^{-1}(\mathrm{~g})$ and fresh seed yield plant ${ }^{-1}$ (g)were collected on ten randomly selected plants (avoiding border plants) in each of the two $F_{1}$ 's and three parents in each replication and on each of 212 and 229 individual plants in $\mathrm{F}_{2}$ generation of HA $10-8 \times$ RIL 180 and FPB $21 \times$ RIL 180, crosses respectively. Similarly, data on different quantitative traits were collected on 8 random plants (avoiding border rows) from each of the $17 \mathrm{~F}_{3}$ families derived from the cross HA 10-8 $\times$ RIL 180 and on 10 random plants (avoiding border rows) from each of the $31 \mathrm{~F}_{3}$ families derived from FPB $21 \times$ RIL 180 .

\section{Statistical analysis}

The Quantitative traits (QTs) data on individual plants of $\mathrm{F}_{2}$ and $\mathrm{F}_{3}$ populations derived from the two crosses were used for statistical analysis. The total variation in $F_{3}$ populations derived from the two crosses was partitioned in to "between $\mathrm{F}_{3}$ families" and "within $\mathrm{F}_{3}$ families" (Table 1).

Descriptive statistics such as standardized range and phenotypic coefficient of variation (PCV) for nine quantitative traits were computed, to examine adequacy of variability for quantitative traits in $\mathrm{F}_{2}$ and $\mathrm{F}_{3}$ populations to provide statistical justification for the use of skewness and kurtosis for interpretation on the genetics of quantitative traits.

\section{Quantitative traits standardized range}

The highest and lowest QTs mean were used to estimate the range (highest-lowest trait mean) and the same was standardized as standardized range in $\mathrm{F}_{2}$ and $\mathrm{F}_{3}$ populations as ((highest-lowest QT mean)/ $\bar{y}$ ), Where, $\bar{y}=$ Population mean of QTs

\section{Quantitative traits phenotypic variance and phenotypic coefficient of variation}

In $F_{2}$ populations, QTs phenotypic variance was computed as $\sigma_{\mathrm{F}_{2}}^{2}=1 / n-1\left[\sum\left(y_{i}-\bar{y}\right)^{2}\right]$

Where, $y_{i}=\mathrm{QT}$ value of $\mathrm{F}_{2}$ individuals; $\bar{y}=$ Population mean of QT

$\mathrm{n}=$ Number of individuals in each of $\mathrm{F}_{2}$.

In $F_{3}$ population, $Q T s$ phenotypic variance was computed using the information from ANOVA of $\mathrm{F}_{3}$ families as; 
Phenotypic variance $\left(\sigma_{\mathrm{F}_{3}}^{2}\right), \sigma_{\mathrm{p}}^{2}=\sigma_{\mathrm{A}}^{2}+\sigma_{\mathrm{e}}^{2}$, Where, $\sigma_{\mathrm{A}}^{2}=$ additive genetic variance

$\sigma_{\mathrm{e}}^{2}=$ error variance $=\sigma_{\mathrm{w}}^{2}-1 / 2 \sigma_{\mathrm{A}}^{2} ; \sigma_{\mathrm{w}}^{2}=\mathrm{MS}_{2}$

Phenotypic variances were standardized as phenotypic coefficient of variation (PCV) to facilitate comparison across QTs.

Phenotypic coefficient of variation $(\mathrm{PCV})=$ $\sigma_{p} / \bar{y} \times 100$,

Where, $\sigma_{p}=$ Phenotypic standard deviation; $\bar{y}=$ Population mean of QTs

\section{Third and fourth degree statistics-based genetics}

The skewness and kurtosis were estimated using 'SPSS' software program to understand the nature of genetic control of target traits. Skewness describes the degree of departure of a distribution from symmetry. Genetic expectations of skewness $\left(-3 / 4 d^{2} h\right)$ reveal the nature of genetic control of the traits. The parameters' $d$ ' and ' $h$ ' represent additive and dominance genetic effects, respectively. Trait variation in $F_{2}$ and $F_{3}$ populations is by and large caused by additive and additive $x$ additive epistasis as dominance and dominance-based epistasis will dissipate with increase in homozygosity (3).

Therefore, genetic expectation of coefficient of skewness of the distribution of $F_{2}$ and $F_{3}$ populations is a function of number of genes and the parameters that specify their additive main genetic and digenic additive $\times$ additive epistatic interaction effects. Kurtosis characterizes the degree of peakedness of a distribution relative to normal distribution. Positive kurtosis ( $>3$ ) indicate leptokurtic distribution, caused by fewer number of genes controlling quantitative traits, while negative kurtosis $(<3)$ indicate platykurtic distribution, caused by large number of genes controlling quantitative traits. Thus, Kurtosis indicates the relative number of genes controlling the trait under investigation.

\section{Results and Discussion}

\section{Variability in segregating populations}

Analysis of variance indicated significant variability among and within $\mathrm{F}_{3}$ families, for all the nine quantitative traits in both the crosses (Tables 2a and 2b). This could be attributed to wide variation between $F_{2}$ plants and heterozygosis at several loci for which the parents differed. The analysis of variance served as a diagnostic step for detecting variability for QTs and provided justification for estimating variability parameters such as standardized range and PCV. In both the crosses, standardized range was wider for racemes plant ${ }^{-1}$, raceme length, fresh pods plant $^{-1}$ and fresh pod weight plant ${ }^{-1}$, while it was narrow for rest of the traits in $\mathrm{F}_{2}$ and $\mathrm{F}_{3}$ populations (Table 3). The estimates of PCV which represent true reflection of variability (unlike standardized range which is biased by extreme values) were relatively higher for the traits for which standardized range was wider. Thus, the estimates of standardized range and PCV complemented each other in revealing the variability in $\mathrm{F}_{2}$ and $\mathrm{F}_{3}$ populations.

\section{Third and fourth degree statistics based genetics}

Fisher et al., (1932) outlined the theoretical basis of usefulness of skewness for explaining the genetic causes for variation in quantitative traits. The skewed distribution of a trait in general suggests that the trait is under the control of non-additive gene action, especially epistasis and is influenced by non-genetic sources of variability (4). Positive skewness is caused by duplicate gene interactions predominantly in the same directions. 
Int.J.Curr.Microbiol.App.Sci (2017) 6(10): 2551-2558

Table.1 Structure of ANOVA of $\mathrm{F}_{3}$ families

\begin{tabular}{|c|c|c|c|c|c|c|c|c|c|c|c|c|}
\hline \multicolumn{5}{|c|}{ Source of variation } & \multicolumn{2}{|l|}{ df } & \multicolumn{2}{|l|}{ MSS } & \multicolumn{4}{|c|}{$\mathrm{E}(\mathrm{MSS})$} \\
\hline \multicolumn{5}{|c|}{ Between $\mathrm{F}_{3}$ families } & $(n-1)$ & & $\mathrm{MS}_{1}$ & & \multicolumn{4}{|c|}{$\sigma_{\mathrm{w}}^{2}+\mathrm{k} \sigma_{\mathrm{b}}^{2}$} \\
\hline \multicolumn{5}{|c|}{ Within $\mathrm{F}_{3}$ families } & $\mathrm{n}(\mathrm{k}-1)$ & & $\mathrm{MS}_{2}$ & & \multicolumn{4}{|l|}{$\sigma_{\mathrm{w}}^{2}$} \\
\hline \multicolumn{13}{|c|}{$\begin{array}{l}\mathrm{n}=\text { number of families; } \mathrm{k}=\text { number of plants within each } \mathrm{F}_{3} \text { family } \\
\sigma^{2}{ }_{b}=\text { between } \mathrm{F}_{3} \text { family variance; } \sigma^{2}{ }_{w}=\text { within } \mathrm{F}_{3} \text { familyvariance }\end{array}$} \\
\hline \multicolumn{13}{|c|}{ Table.2a Analysis of variance of $F_{3}$ families derive } \\
\hline \multirow{3}{*}{ ce of } & \multirow{2}{*}{\multicolumn{2}{|c|}{ Degrees of freedom }} & \multicolumn{10}{|c|}{ Mean sum of squares } \\
\hline & & & \multicolumn{2}{|c|}{ Days to flowering } & \multicolumn{2}{|c|}{ Plant height $(\mathrm{cm})$} & \multicolumn{2}{|c|}{$\begin{array}{l}\text { Primary branches } \\
\text { plant }^{-1}\end{array}$} & \multicolumn{2}{|c|}{ Racemes plant $^{-1}$} & \multicolumn{2}{|c|}{ Raceme length $(\mathrm{cm})$} \\
\hline & $\mathrm{C}_{1}$ & $\mathrm{C}_{2}$ & $\mathrm{C}_{1}$ & $\mathrm{C}_{2}$ & $\mathrm{C}_{1}$ & $\mathrm{C}_{2}$ & $\mathrm{C}_{1}$ & $\mathrm{C}_{2}$ & $\mathrm{C}_{1}$ & $\mathrm{C}_{2}$ & $\mathrm{C}_{1}$ & $\mathrm{C}_{2}$ \\
\hline een $\mathrm{F}_{3}$ families & 16 & 30 & $24.03 * *$ & $54.46 * *$ & $178.02 * *$ & $193.98^{* *}$ & $1.76^{* *}$ & $3.50 * *$ & $5.89 * *$ & $9.40 * *$ & $79.95 * *$ & $58.69 * *$ \\
\hline in $\mathrm{F}_{3}$ families & 119 & 279 & 1.55 & 2.61 & 8.95 & 10.68 & 0.15 & 0.19 & 0.38 & 0.70 & 5.75 & 1.04 \\
\hline
\end{tabular}

Table.2b Analysis of variance of $\mathrm{F}_{3}$ families derived from two crosses for quantitative traits in dolichos bean

\begin{tabular}{|c|c|c|c|c|c|c|c|c|c|c|}
\hline \multirow{3}{*}{$\begin{array}{l}\text { Source of } \\
\text { variation }\end{array}$} & \multirow{2}{*}{\multicolumn{2}{|c|}{ Degrees of freedom }} & \multicolumn{8}{|c|}{ Mean sum of squares } \\
\hline & & & \multicolumn{2}{|c|}{ Fresh pods raceme ${ }^{-1}$} & \multicolumn{2}{|c|}{ Fresh pods plant ${ }^{-1}$} & \multicolumn{2}{|c|}{$\begin{array}{l}\text { Fresh pod } \\
\text { weight } \text { plant }^{-1}(\mathrm{~g})\end{array}$} & \multicolumn{2}{|c|}{$\begin{array}{l}\text { Fresh seed } \\
\text { weight plant }^{-1}(\mathrm{~g})\end{array}$} \\
\hline & $\mathrm{C}_{1}$ & $\mathrm{C}_{2}$ & $\mathrm{C}_{1}$ & $\mathrm{C}_{2}$ & $\mathrm{C}_{1}$ & $\mathrm{C}_{2}$ & $\mathrm{C}_{1}$ & $\mathrm{C}_{2}$ & $\mathrm{C}_{1}$ & $\mathrm{C}_{2}$ \\
\hline Between $\mathrm{F}_{3}$ families & 16 & 30 & $1.06^{* *}$ & $2.58 * *$ & $160.98 * *$ & $204.05^{* *}$ & $157.10^{* *}$ & $981.98 * *$ & $111.90 * *$ & $54.84 * *$ \\
\hline
\end{tabular}


Int.J.Curr.Microbiol.App.Sci (2017) 6(10): 2551-2558

Table.3 Estimates of standardized range and phenotypic coefficient of variation for quantitative traits in $\mathrm{F}_{2}$ and $\mathrm{F}_{3}$ populations derived from two crosses in dolichos bean

\begin{tabular}{|c|c|c|c|c|c|c|c|c|}
\hline \multirow{3}{*}{ Traits } & \multicolumn{4}{|c|}{ Standardized range } & \multicolumn{4}{|c|}{ Phenotypic coefficient of variation } \\
\hline & \multicolumn{2}{|c|}{ HA $10-8 \times$ RIL 180} & \multicolumn{2}{|c|}{ FPB $21 \times$ RIL 180} & \multicolumn{2}{|c|}{ HA $10-8 \times$ RIL 180} & \multicolumn{2}{|c|}{ FPB $21 \times$ RIL 180} \\
\hline & $\mathrm{F}_{2}$ & $\mathrm{~F}_{3}$ & $\mathrm{~F}_{2}$ & $\mathrm{~F}_{3}$ & $\mathrm{~F}_{2}$ & $\mathrm{~F}_{3}$ & $\mathrm{~F}_{2}$ & $\mathrm{~F}_{3}$ \\
\hline Days to flowering & 0.31 & 0.26 & 0.28 & 0.33 & 8.42 & 4.21 & 6.71 & 5.69 \\
\hline Plant height $(\mathrm{cm})$ & 0.77 & 0.88 & 0.92 & 0.99 & 13.64 & 11.16 & 14.59 & 10.61 \\
\hline Primary branches plant ${ }^{-1}$ & 1.67 & 1.76 & 1.40 & 1.93 & 21.10 & 20.98 & 30.12 & 27.74 \\
\hline Racemes plant $^{-1}$ & 2.37 & 2.32 & 1.92 & 3.91 & 40.03 & 21.70 & 37.09 & 27.17 \\
\hline Raceme length $(\mathrm{cm})$ & 2.28 & 2.13 & 1.75 & 3.18 & 31.03 & 28.62 & 34.48 & 21.08 \\
\hline Fresh pods raceme ${ }^{-1}$ & 1.27 & 1.06 & 1.51 & 1.71 & 21.58 & 9.97 & 26.36 & 11.97 \\
\hline Fresh pods plant $^{-1}$ & 2.63 & 2.68 & 2.26 & 2.26 & 44.48 & 22.91 & 41.29 & 26.26 \\
\hline Fresh pod weight plant $^{-1}(\mathrm{~g})$ & 2.14 & 1.84 & 2.18 & 2.29 & 32.28 & 16.14 & 29.53 & 30.86 \\
\hline Fresh seed weight plant ${ }^{-1}(\mathrm{~g})$ & 1.98 & 1.68 & 2.57 & 1.86 & 23.65 & 18.16 & 29.09 & 14.97 \\
\hline
\end{tabular}

Table.4 Estimates of skewness and kurtosis for quantitative traits in $\mathrm{F}_{2}$ and $\mathrm{F}_{3}$ populations derived from two crosses in dolichos bean

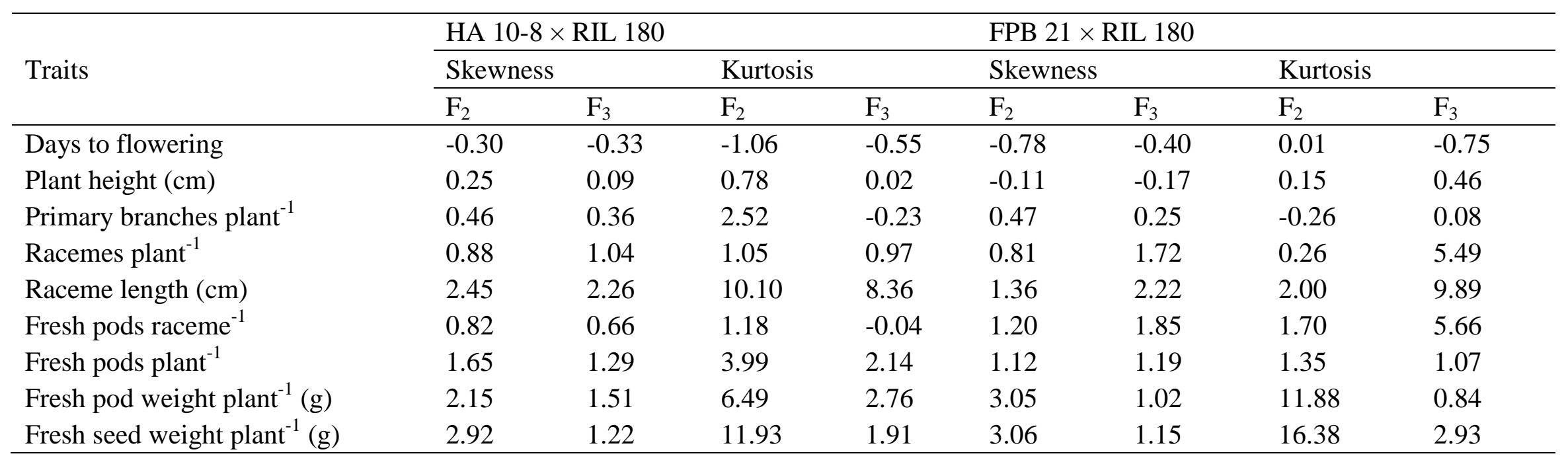


Complete ambi-directional epistasis however produces kurtosis while distribution stays symmetrical around the mean. The genes controlling the trait with skewed distribution tend to be predominantly dominant irrespective of whether they have increasing or decreasing effects on the expression of trait.

Positively skewed and platykurtic distribution of $F_{2}$ and $F_{3}$ populations suggest that the expression of the traits are controlled by large number of genes with complementary epistasis. The positively skewed distribution also suggested that the genes at the corresponding trait loci exhibit decreasing effects and indicate that the genetic gain could be rapid with mild selection and less rapid with intense selection for target traits.

In the present study, near normal platykurtic distribution of $\mathrm{F}_{3}$ population derived from HA 10-8 $\times$ RIL 180 suggested the occurrence of high frequency of plants with intermediate plant height and controlled by large number of genes (Table 4). Negatively skewed platykurtic distribution suggested the involvement of large number of genes with majority of them displaying duplicate epistasis in the expression of days to flowering in HA 10-8 $\times$ RIL 180 cross and days to flowering and plant height in both $\mathrm{F}_{2}$ and $\mathrm{F}_{3}$ populations derived from FPB $21 \times$ RIL 180 cross.

Positively skewed platykurtic distribution suggested the involvement of large number of genes with majority of them displaying complementary epistasis with increasing effects on the expression of plant height, primary branches plant $^{-1}$, racemes plant $^{-1}$, fresh pods raceme ${ }^{-1}$ in $F_{2}$ population and for plant height, primary branches plant $^{-1}$, racemes plant $^{-1}$, fresh pods raceme ${ }^{-1}$, fresh pods plant $^{-1}$, fresh pod weight plant $^{-1}$ and fresh seed weight plant ${ }^{-1}$ in $F_{3}$ population derived from HA 10-8 $\times$ RIL 180. Similarly, positively skewed platykurtic distribution indicated the role of large number of genes with increasing effects on the expression of primary branches plant $^{-1}$, racemes plant ${ }^{-1}$, raceme length, fresh pods raceme ${ }^{-1}$ and fresh pods plant ${ }^{-1}$ in $F_{2}$ and for primary branches plant $^{-1}$, fresh pods plant ${ }^{-1}$, fresh pod weight plant $^{-1}$ and fresh seed weight plant ${ }^{-1}$ in $F_{3}$ population derived from FPB $21 \times$ RIL 180 cross. Expected genetic gain is slow with mild selection while it is rapid with intense selection for the improvement of these traits. Researchers such as (5) in Brassica oleracia and (6) in sorghum, (7) in dolichos bean also detected complementary epistasis between increasing effects genes controlling economically important traits using skewness and kurtosis. They further suggested intense selection for rapid genetic gain for the traits investigated.

Positively skewed leptokurtic distribution indicated the role of fewer number of genes with majority of them exerting decreasing effects on the expression of raceme length in both $F_{2}$ and $F_{3}$ populations, while only for fresh pods plant ${ }^{-1}$, fresh pod weight plant ${ }^{-1}$ and fresh seed weight plant ${ }^{-1}$ in $\mathrm{F}_{2}$ population derived from HA 10-8 $\times$ RIL 180. Similarly, positively skewed leptokurtic distribution indicated involvement of fewer genes with decreasing effects in the expression of fresh pod weight plant ${ }^{-1}$ and fresh seed weight plant $^{-1}$ in $\mathrm{F}_{2}$ and for racemes plant ${ }^{-1}$, raceme length and fresh pods raceme ${ }^{-1}$ in $\mathrm{F}_{3}$ population derived from FPB $21 \times$ RIL 180 cross. Intense selection might be necessary to realize rapid gain in the expression of genotypes with higher number of the corresponding traits. Thus, skewness and kurtosis served as valuable tools and provided comprehensive and mutually complementary information on the mode of action of genes controlling fresh pod yield and its component traits in dolichos bean. 


\section{References}

1. Chandrakant, Ramesh S., Vaijayanthi PV, Raithamithra. 2014. http://raitamitra.kar.co.in/

2. Keerthi CM, Ramesh S, Byre Gowda M, Mohan Rao A, Marry Reena GA, Chandrakant (2014) Performance stability of Photoperiod sensitive vs. insensitive Dolichos bean (Lablab purpureus L. var. Lignosus) cultivars under delayed sowing conditions. Australian J. Crop Sci. 8(12): 1658-1662.

3. Xu, Y. 2010. Molecular Plant Breeding, $\mathrm{CAB}$ International, Wallingford, UK, Pp. 132.

4. Keerthi CM, Ramesh S, Byregowda M, Chandrakant N, Vaijayanthi PV, Shivakumar MS, MohanRao A (2015) Epistasis-driven bias in the estimates of additive and dominance genetic variance in dolichos bean (Lablab purpureus L.) J. Crop Improv. 1-25.

5. Zhang, N. Y. and Zhou, W. 2006. Genetic analysis of agronomic and seed quality traits of synthetic oilseed Brassica napus produced from inter-specific hybridization of Brassica campestrisand Brassica oleracea. J. Genetics, 85 (1): 45-51.

6. Jayaramachandran, M., Kumaravadivel, N and Kandaswamy, G. 2010. Gene action for yield attributing characters in segregating generations $\left(\mathrm{M}_{2}\right)$ of sorghum (Sorghum bicolor L.) Electronic J. Pl. Breed., 1(4): 808-805.

7. Chandrakant, Ramesh S, Vaijayanthi PV, Byre Gowda M, Mohan Rao A, Keerthi CM, Shivakumar MS (2015) Impact of $\mathrm{F}_{2}$ bi-parental on quantitative traits interrelationships and frequency of transgressive segregants in Dolichos bean (Lablab purpureus L.) Electronic J. Plant. Breeding. 6(3): 723-728.

\section{How to cite this article:}

Showkath Babu, B.M., B.N. Jagadeesh, S. Ramesh, C.M. Keerthi and Sowmya, H.H. 2017. Third and Fourth Degree Statistics-Based Genetics of Quantitative Traits in Dolichos Bean (Lablab purpureus L.). Int.J.Curr.Microbiol.App.Sci. 6(10): 2551-2558. doi: https://doi.org/10.20546/ijcmas.2017.610.299 